\title{
Computational identification of promoters and first exons in the human genome
}

R V Davuluri, I Grosse \& M Q Zhang

Nature Genet. 29, 412-417 (2001).

Published online 26 November 2001; doi:10.1038/ng780

On page 413, the last line of the caption of Fig. 2 should read “... the CpG window overlapped with the region ranging from -200 bp of the transcription start site to the splice-donor site."

On page 414, the last sentence of the caption of Table 2 should read "Approximately $70 \%$ of those 58 promoters are CpG-related."

\section{High-throughput retroviral tagging to identify components of specific signaling pathways in cancer}

H Mikkers, J Allen, P Knipscheer, L Romeyn, A Hart, E Vink \& A Berns

Nature Genet. 32, 153-159 (2002).

Published online 19 August 2002; doi:10.1038/ng950

The name of the fourth author was misspelled as Lieke Romeyn rather than the correct spelling: Like Romeijn.

\section{The gene mutated in juvenile nephronophthisis type 4 encodes a novel protein that interacts with nephrocystin}

\author{
G Mollet, R Salomon, O Gribouval, F Silbermann, D Bacq, G Landthaler, D Milford, A Nayir, G Rizzoni, C Antignac \& S Saunier
}

Nature Genet. 32, 300-305 (2002).

Published online 9 September 2002; corrected 3 October 2002 (details online); doi:10.1038/ng996

A sequence analysis error (deletion of two cytosine residues) occurred in the previously named exon -4 . This masked a methionine codon located 176 amino acids upstream of the previously reported initiation codon. Correction of this error indicates that NPHP4 contains four additional coding exons, and the protein nephrocystin-4 is composed of 1,426 amino acids instead of 1,250. The exons should be renumbered as follows: exon -5 becomes exon 1, the initiation codon is in exon 2 and the last exon is exon 30 . The designations of all the mutations have changed as shown in the following revised version of Table 1.

\begin{tabular}{|c|c|c|c|c|c|}
\hline Type of mutation & Nucleotide change $\mathrm{a}^{\mathrm{a}}$ & Amino-acid change & Exon & Individual affected & Mutation Status ${ }^{b}$ \\
\hline \multirow[t]{3}{*}{ nonsense } & $2044 C \rightarrow T$ & Arg682X & exon 16 & $\mathrm{~F} 18^{\mathrm{c}}$ & het \\
\hline & $2368 \mathrm{G} \rightarrow \mathrm{T}$ & Glu790X & exon 18 & $\mathrm{~F} 115^{\mathrm{d}}$ & hom \\
\hline & $2377 \mathrm{C} \rightarrow \mathrm{T}$ & $G \ln 793 X$ & exon 18 & F96 & hom \\
\hline frameshift & 3272delTe & Val1091fsX1121 & exon 23 & $\mathrm{~F} 171^{\mathrm{C}}$ & het \\
\hline missense & $2972 T \rightarrow C$ & Phe991Ser & exon 21 & $\mathrm{~F} 95^{\mathrm{d}}$ & hom \\
\hline \multirow[t]{3}{*}{ polymorphism } & $2219 G \rightarrow A^{f}$ & Arg740His & exon 17 & & \\
\hline & $2542 \mathrm{C} \rightarrow \mathrm{T}$ & Arg848Trp & exon 19 & & \\
\hline & $2818-2 A \rightarrow T$ & $\Delta$ Ala940-Gln941 & exon 21 & & \\
\hline
\end{tabular}

